\title{
Herodes - die Grote?
}

Pieter J J Botha

Universiteit van Suid-Afrika

\begin{abstract}
Herod - The Great?

The claim to historical understanding is more than simply quoiing from ancient sources. Not only must anachronism and ethnocentrism be dealt with in order not to make the ancients mere instruments of modern preferences, but the sources themselves must be carefully interpreted so that we do not become victims of their propaganda. The challenge of historical understanding with sincerity and fairness is illustrated in this study of Herod the Great, king of the Judaeans. Studying history is not to aim at the discovery of final truth, but to participate in the conversation about truth, and therefore the self-reflection and self-discovery implied by historical exploration.
\end{abstract}

\section{PROBLEEMSTELLING}

Met die doel 'om aan die student 'n betroubare en oorsigtelike gids' van Israel se geskiedenis te bied (Van Zyl 1977:v) skryf Jurie Le Roux (1977:276) die volgende:

Herodes die Grote was bevrees dat Christus se geboorte tot opstand in sy ryk sou aanleiding gee. Daarom wou hy graag deur middel van die wyse manne meer inligting aangaande Hom bekom. Toe hy bemerk het dat hulle hom mislei het, het hy opdrag gegee dat alle seuntjies onder twee jaar in Bethlehem en omstreke vermoor moet word (Matt 2).

Hoe betroubaar is hierdie kort karakterisering? Hoe sou mens hierdie 'feite' kon uitvind?

In 'n handboek, 'bedoel as handleiding vir die kennis van Bybelse geskiedenis' (Groenewald 1968:21) wat verskeie herdrukke beleef het en vir meer as 'n dekade deur bykans alle (Afrikaanssprekende) Bybelkunde studente gelees is, lees ons die volgende:

[Die navraag van die wyse manne] ... bereik die ore van Herodes.

Onmiddellik maak dit sy agterdog en naywer gaande .... Aangesien 
Herodes geen teenstander in die lewe laat bly nie en selfs van sy eie seuns vermoor het, wil hy ook werk maak van hierdie nuwe bedreiging van sy troon. Die inwoners van Jerusalem ken Herodes en sy hartelose wreedheid, en vrees dat hy ' $n$ ramp oor die stad kon bring ....

Dit het nie lank geduur nie of Herodes ontdek dat die wyse manne hom uitoorlê het. Hy was woedend .... Dus, alle seuntjies van twee jaar en daaronder in die omgewing van Betlehem moes gedood word. Die koning wat vir bloedvergieting nooit teruggedeins het nie, gee die onmenslike bevel.

(Groenewald 1968:79, 81-82)

Herodes se optredes 'getuig van agterdog, nydigheid en sluwe beplanning', want 'geen daad is vir hom te gemeen nie om sy eie regeermag te handhaaf' (Groenewald 1968:34)1. Ook Le Roux (1977:273) reken: 'Handhawing van sy mag en troon was sy leuse, en in die uitvoering hiervan het hy die wreedste metodes nie ontsien nie'. Dit is veral die opvatting dat Herodes 'n kindermoordenaar was wat beslissend werk: immers, het hy nie geskroom om sy eie seuns dood te maak nie?

Is dit betroubare geskiedenis wat ons hier vind? Dié vraag roep 'n ander een op, naamlik hoe ons met ons bronne moet omgaan? Dit sluit ook in hoe ons Matteus 2 moet opneem. Bogenoemde karakteriserings word sekerlik reeds deur Matteus gesuggereer, tog nie?

Maar ook ernstige vrae oor morele waardes en die beoordeling van die 'regte daad' ontstaan. Sou bogenoemde skrywers gelukkig en tevrede gewees het as Alexander en Aristobulus wél hulle pa vermoor het en dan self geregeer het ${ }^{2}$ ? Het ons dan minder besware teen vadermoord?

Talle skrywers verwys ook na Herodes se gebrek aan vroomheid. Josefus het natuurlik hierdie beskuldiging begin. Dit loon ons dalk om te vra of Herodes godsdienstig was. Of was hy maar net 'n 'heiden' wat gepretendeer het om ook 'n Jood te wees? Wat lê agter karakteriserings soos 'wetteloos', 'goddeloos', 'ongelowig' ensomeer? Wanneer, en op watter gronde mag ons sulke uitsprake maak?

\section{GESKIEDSKRYWING}

Niemand sal dit betwis dat dit uiters moeilik is om enigiets uit te vind van iemand wat 2000 jaar gelede geleef het nie. Die probleme word net nog meer indien die persoon 'n kontroversiële figuur was ${ }^{3}$. Die 'gegewens' van 'n omstrede persoon se lewe word selektief bewaar, en word verder verleidelik aangebied; met verloop van tyd word hier- 
die gegewens 'tradisie' wat meer en meer 'gekleurd' raak. En, dit kan nie buite rekening gelaat word dat onsself ' $n$ selekterende, interpretatiewe raamwerk het wat die gegewens in 'n rigting wil druk.

So ontstaan daar 'n implisiete storie wat die verstaan en die gevolglike diskoers (die conversation on the world) waaraan ons deelneem, beïnvloed. Selfs kompetente geskiedskrywers trap gemaklik in die strikke wat deur die lyne van so 'n populêre narratief gestel word. Vanuit 'n menigte moontlike voorbeelde kan ons die volgende paragraaf bekyk:

\begin{abstract}
Herod thereupon [na sy verhoor omdat hy Hesekia en die se bende uitgewis het] wanted to attack Jerusalem, but he was restrained by Antipater and Phasael. Antipater rightly understood that a new civil war would do no good to his own position and that of his sons. During his conflict with the Sanhedrin, Herod's position was considerably strengthened by his nomination as strategos of Coele-Syria, and probably also of Samaria, by Sextus Caesar.
\end{abstract}

(Jagersma 1985:100)

Let op wat word alles nie vertel nie. Het Herodes nou gedink om Jerusalem aan te val met die klein groepie wagte wat hom vergesel het? Ons weet minstens een ding, naamlik dat Herodes nie onnosel was nie .... Duidelik moes Herodes aansienlike populêre steun geniet het. Trouens, so gesien maak die verwysing na 'a new civil war' sin. Maar let op die talle ander probleme. Terwyl Herodes tot die aanval wil aangaan, kan sy pa en broer blykbaar vryelik rondbeweeg. Hy is in konflik met die Sanhedrin, maar die Romeinse goewerneur, wat vrede (= die minimum moeilikheid) met die Judeërs soek, stel Herodes aan ....

Wat Jagersma doen, is om Josefus oor te skryf en nie te interpreteer nie. Josefus het 'n groot-man-geskiedfilosofie, en meeste van sy lesers (Josefus s'n) dink blykbaar dit is wat ons ook moet doen, naamlik 'n voorstelling van die geskiedenis aanbied in terme van die sogenaamde 'prominente' manlike akteurs: 'Toe het hy .... Daarna het hy .... En toe het hy ....' Asof 'n 'hy' 'n stad kan inneem, 'n land kan regeer en die 'geskiedenis' kan stuur.'

Die kernprobleem met baie van sulke geskiedskrywing is die naïewe geloof dat interpretasie nie nodig is nie. Byvoorbeeld: 'His rule was characterized by the greatest possible cruelty, of which a number of examples are given in both Jewish and Christian literature, although that is not always very objective' (Jagersma 1985:106). Wat 
beteken 'not always very objective'? Dié opmerking wys na 'n opvatting oor historiese getuienis. Die getuienis (evidence) is daar, die enigste probleem is om die betroubares uit te soek. So 'n opvatting steek net weg dat die historikus eintlik sê dat hy/sy reeds verstaan en dus net die nodige bewyse daarvoor soek.

'n Verdere probleem met so 'n benadering is die veronderstelling dat ons in Herodes se hart en verstand kan insien - wat Josefus natuurlik geglo het hy kan doen - en dat dinge gebeur omdat sekere mense besluit om dit te laat gebeur.

\subsection{Terme en konsepte}

In alle pogings tot historiese interpretasie moet ons noodwendig terme en konsepte gebruik. En die data voor hande konfronteer ons met sekere terme en konsepte. Maar dikwels lê die uitdaging juis hierin opgesluit. Ons is nou al dekades lank bewus van die probleem om vertalingsekwivalente nie summier gelyk te stel met betekenis nie. Tog word talle studies juis deurspek met hierdie naïwiteit.

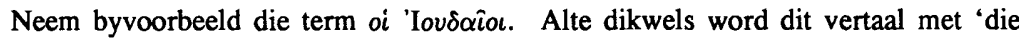
Jode', terwyl dit meesal - en veral in Josefus (ook in Matteus?) - verwys na die Judeërs, soos in Edomeërs en Galileërs. Ons onderskat die kompleksiteite van destyds en smeer die gefragmenteerde diversiteit toe met ons terme, soos 'die Jode'. Dikwels gebeur dit omdat sulke aksies óns opvattinge pas.

'n Verwante aspek is die gemaklike steun wat die anklag teen Herodes onder moderne skrywers geniet, naamlik dat hy nie 'n ware Jood was nie 4 . Maar onthou: die Galileërs en Edomeërs is deur die Hasmoneërs (die 'party' wat Herodes so opdraend gegee het, en hom oënskynlik nie wou aanvaar nie) met geweld geforseer om 'Joods' te word 5 . Van Herodes se geslag spesifiek was daar sekerlik nog mense wie se oupas en oumas (en waarskynlik nog baie se ma's en pa's) die gedwonge besnydenis van die manne ervaar of onthou het. Om Herodes te beskou as nie 'n Jood nie (vanuit Hasmonese oogpunt) is 'n manier om verantwoordelikheid vir die geskiedenis te ontken: om iemand te verkwalik vir wat mens self aan hulle gedoen het. Dit is nie billik om mense gewelddadig in te lyf, en dan die onderworpenes te verkwalik nie.

'n Ander voorbeeld is die $\lambda \eta n \sigma \alpha i$, die beroemde of berugte bandits ${ }^{6}$. In ons hantering van hierdie begrip gebruik ons in elk geval die een of ander verstaansmodel. Ons sien hulle implisiet as iets wat ons ken. Dus, sal ons hulle voorstel of as neo-nazi skobbejakke of as MK dapper helde?

Ons weet dat Josefus nie van die bendes gehou het nie, en dat Herodes hulle sterk teëgestaan het. Dit is die redes wat die akkurate voorstelling van hierdie groepe so moeilik maak. Was hulle teenstanders van Herodes of van 'die gemeenskap'? Josefus sê dat dit veral dié is wat godsdiens vir gewelddadige gewin inspan, wat die mees 
onheilspellende boosheid verteenwoordig (BJ 2:254-263). Diegene wat Herodes sien as die groot onderdrukker, die koloniale uitbuiter, sien die bendes as vryheidsvegters. Ons weet dat sommige van hierdie bendes fanaties nasionalisties was - is dit noodwendig 'n goeie waarde? En hoe sou diegene wat onder die bandits deurgeloop het, geoordeel het?

Dit is uiters belangrik dat ons versigtig kies met ons terme, want sodoende kan ons daarteen waak om slagoffers van die propaganda van ons bronne te word. Maar ons moet ook baie hard werk aan ons verstaansmodelle, anders word húlle (the other) slagoffers van óns propaganda.

\subsection{Etnosentrisme en anakronisme}

Die konteks van bogenoemde probleem is natuurlik die voortdurende gevaar om etnosentries en anakronisties te interpreteer.

'n Opvallende probleem wat navore kom wanneer mens Herodes die Grote bestudeer, is antieke politiek. Male sonder tal word Herodes veroordeel, en dan is dit duidelik dat die betrokke skrywer veronderstel dat Herodes alternatiewe wat eers in die moderne era tot stand gekom het, kon gekies of toegepas het. Met ander woorde, die uitdaging is om antieke politiek as antieke politiek te verstaan. Antieke politieke verwikkelinge kan nie gemeet of verstaan word met kontemporêre demokratiese konsepte nie $^{7}$. 'n Eenvoudige aspek is, byvoorbeeld, die feit dat mag in die interaksie van verskeie groepe bestaan; suksesvolle maguitoefening is om die balans tussen die verskillende groepe se behoeftes, belange en waardes te vind. Om 'n koningskap van die tydperk, 'n halfeeu voor Christus te verstaan, moet ons die waardes en magsmoontlikhede wat destyds bestaan het, verreken. In Rome, byvoorbeeld, moes die keiser 'n balans vind tussen die leërs, die plebs, die senaat, die provinsies en die 'filosowe/digters' (vgl Botha 1989:52). 'n Keiser (of 'n vasalkoning) wat dinge nie bymekaar kon hou nie, het nie lank geregeer nie. Met ander woorde, Herodes sou nie net met 'n effektiewe leërmag kon regeer nie, maar moes aansienlike steun geniet het; daarsonder is dit onmoontlik om enigiets te vermag.

Die konsep monargie was gebaseer op 'n waardesisteem wat in wese religieus, paternalisties en konserwatief was. Die 'goddelike reg' (of goddelike fundering) van die heerser as waarde, was destyds 'n gegewene. Dit sluit Hellenistiese, GrieksRomeinse en Joodse denke in (Friedrich 1968; Bracher 1987:615; Charlot 1987; Kleinknecht et al 1964; Rawson 1975).

Dit kom dus neer op die besef dat ons met 'n ander wêreld te doen het. Daar is soveel voorbeelde dat dit vreemd en ongemaklik vir my is om 'n kwessie daarvan te maak, maar die nalaat van hierdie probleem is juis vir my voortdurend in die oog. In 
40 v C het die Partiërs Sirië aangeval. Lisanias (van die Itureërs) en Antigonus Mattias het hier die geleentheid gesien om Antigonus 'koning van die Jode' te maak, en het Pakorus (seun van die Partiese satrap Barsafarnes) oortuig om hom te steun in sy poging om sodanige alleenheerskappy teenoor Herodes (en Antipater, Herodes se pa, en Hirkanus) te bekom. Sonder enige verduideliking meld Josefus (BJ 1.248) dat die Partiër oorgehaal is deur die aanbod van Lisanias, naamlik eenduisend talente en vyfhonderd vroue. Dis nou die nie-Herodiaanse Joodse groep, met Hasmonese agtergrond (die politieke alternatief vir Herodes, dus) wat met sulke waardes werk.

Hierdie selfde Antigonus het gesorg dat Hirkanus nooit weer hoëpriester sou kon word nie (BJ 1.270). Blykbaar het hierdie mense Lev 21:17-23 so geïnterpreteer dat iemand wie se ore afgebyt is, nie ander mense voor God kan verteenwoordig nie. Hierdie is waardes wat nie net vir my niks beteken nie, maar eerder dui op 'n patologiese minderwaardigheidskompleks. Elk geval, sommige Judeërs het hierdie Antigonus so hoog aangeslaan dat hulle selfs tydens marteling hom aangeroep het as koning ( $A J$ 15.9).

\section{BRONNE}

\subsection{Josefus}

Mens kan nie sommer net die gedeeltes waarin daar na Herodes die Grote verwys word uit Josefus se tekste uitpluk en 'n 'geskiedenis' daarvan maak nie. Josefus het weliswaar ' $n$ volgehoue belangstelling in die Herodiaanse familie, maar dit is omdat hy in hierdie leiers en prominente persone die geleentheid sien om die temas van sy werke te illustreer. Om sy stories as 'getuienis' te gebruik moet ons die data in daardie konteks plaas.

Die Herodiaanse families word nogal verskillend uitgebeeld in Josefus se werke.

\subsubsection{Die Bellum Judaicum}

In die Joodse Oorlog word Antipater, Herodes se pa, eers aan die leser bekend gestel. Antipater is 'n bekwame, slim goewerneur van Idumea wat weens moed en vernuftige diplomasie die guns van verskeie Romeinse leiers wen en behou. Sy loopbaan kulmineer in sy aanstelling as goewerneur van Judea (deur Kaisar, 47 v C). Hy word voorgestel as ' $n$ betroubare vriend van die Romeine en ' $n$ gedugte opponent van alle rebellie (1.201-203).

Herodes word deur sy pa aangestel as distriksadministrateur ( $\sigma \tau \rho \alpha \tau \eta \gamma o ́ \varsigma)$ van Galilea. Herodes bevry die landstreek van rowers en word gevolglik bewonder deur al die mense. Sommiges is nou wel gekant teen Herodes, maar hulle is kwaadwillige

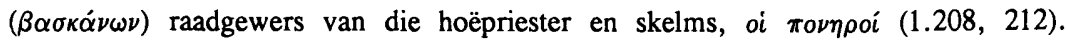


Herodes, so lees ons, is dapper (1.369-385, 429-430), deugdelik, barmhartig (1.295), vroom (1.354-357), begunstig deur die voorsienigheid $(1.331,341)$ en toegewyd aan sy familie (1.263-267). Dit is juis sy suksesse wat ander se jaloesie opwek (1.208).

Wat die uitwissing van sy familielede betref, sê Josefus dat hierdie dade die gevolg is van bose intriges teen die koning: hy is die onskuldige slagoffer van sy gehegtheid aan sy vrou Mariamme (Josefus sê hy was $\mu \alpha \dot{\alpha} \iota \sigma \tau \alpha \dot{\varepsilon} \sigma \pi o v \delta \delta \alpha \sigma \varepsilon \nu$ aan haar). Trouens, Mariamme is sy ondergang $(1.431-440)^{8}$.

Die beskrywing van die Herodiaanse dinastie in die Joodse Oorlog is sodanig dat die apologetiese oogmerk van dié werk na vore kom. Die groot meerderheid Judeërs was nog altyd goedgesind teenoor die Romeine, wat heers omdat God dit goed gevind het. Rebellie is heeltemal vreemd aan die ware Joodse natuur. Dit is in/uit die gedeeltes wat handel oor die tydperk toe Herodes se kleinseuns in Rome meeding om die beste voordeel (na sy dood) en daar heelwat onstuimigheid in Judea ontstaan het, wat Josefus se bedoelinge die beste blyk. In sy beskrywing van hierdie oproerighede beklemtoon Josefus dat dit eintlik die uitsondering onder die Jode is wat opstandige neigings het, alhoewel daar geldige probleme onder die massas bestaan (2.73, 84-89). Hy toon aan dat die rebelleleiers eintlik tiranne is, uit en uit daarop ingestel om persoonlike mag te verkry, terwyl hulle onder hulleself stry en veg en ander Jode terroriseer (2.56-65). Die Romeinse gesag, hierteenoor, is verdraagsaam en ondersteun die onskuldige bevolking (2.75-78).

Presies wanneer Josefus die Herodiaanse prinse se regerings moet behandel, slaan hy oor na 'n uitvoerige uiteensetting van die Esseners se vreedsame lewenswyse wat skril in kontras staan teenoor die rebelle faksies (2.118-166). Josefus verlei sy lesers om die morsige Judese politiek te onderskat en die diepsinnige filosofiese heart and soul van Judaïsme te bewonder.

Agrippa $1^{9}$ word geteken as 'n sentrale figuur in Romeinse politiek: hy onderhandel tussen Klaudius en die Senaat na die moord op Gajus (2.204-213). Agrippa 210 lewer 'n baie mooi toespraak voor diegene wat in opstand wil kom teen Rome: Die Romeine heers omdat God aan hulle kant is; die opstandiges is in stryd met ware Joodse leefwyse en gebruike (2.345-404).

Josefus suggereer eintlik hoe die Romeine moet omgaan met die Joodse mense (onthou, hy skryf post-oorlog). Die Romeine het nie, vroeër, tydens Herodes die Grote se tydperk, toegelaat dat 'minder belangrike' interne woelinge hulle steun en goedkeuring beïnvloed nie. Net so moet die Romeine ook nie nou alle Jode vervolg en verantwoordelik hou vir die probleme wat 'n paar renegate veroorsaak het nie. 


\subsubsection{Die Antiquitates Judaicae}

In die Joodse Oudheidkunde word die geskiedenis van die familie van Herodes anders vertel; die oogmerke van die twee werke verskil grootliks.

Herodes die Grote word in heelwat meer detail uitgebeeld, en baie van die bygewerkte materiaal het ten doel om die morele en godsdienstige tekortkominge van die Herodiaanse dinastie uit te wys. Dit pas natuurlik by die oorwegende motief van die werk: Volgens die ou en edele tradisies van die Judeërs word almal wat van die wette afwyk, gestraf met 'n tragiese dood. Herodes en sy familie bied vir Josefus uitstekende materiaal om hierdie tese te illustreer.

In die verhale word aangetoon hoe die voorsienigheid werk en hoe ver die ketting van gebeure strek wat lei tot ondergang (vgl Attridge 1984, veral bl 220-222). Trouens, Josefus klim kaalvuis in om te wys hoekom Herodes so swaar en gepaardgaande met baie lyding, gesterf het. Gegewe hierdie tipe logika het ons alreeds genoeg rede om die sout by die sakvol nader te trek.

Byvoorbeeld, Antipater word nou bekendgestel as 'n moeilikheidmaker, 'n opruier. Sy invloed is die gevolg omdat hy lieg en bedrieg en agterbakse planne maak om geheime intriges te beoefen (14.8-18). Hy oortree dus die wette en gebruike van Judaïsme.

Dieselfde gebeur met Herodes. Waar die Joodse Oorlog sulke aanklagte inbring teen die boosaardige lede van die hoëpriester se groep (BJ 1.208), sê Josefus in sy Joodse Oudheidkunde dat Herodes 'n oortreder was wat nie geskroom het om te moor nie. Skielik hoor ons ook dat Herodes nie so eenstemmig aanvaar is nie (14.403). So word Herodes deur ene Samaias, 'n opregte man wat verhewe is bo vrees' (14.172) teëgestaan in die Sanhedrin wat Herodes wil aankla. (Maar let op die teenstrydighede: Samaias, die enigste een wat Herodes se intimidasie teenstaan, is die enigste een van al die lede van die Sanhedrin wat nie deur Herodes vermoor word nie.) Ons hoor ook dat 'baie' van die Judeërs nou ongelukkig is met Herodes se aanstelling (15.8-10).

Die moord op die hoëpriester Hirkanus word in detail vertel. In die ander werk was dit 'n ongelukkige insident, deel van Herodes se huislike (interne, onbelangrike) probleme (BJ 1.433-434). Maar nou is dit 'n gebeurtenis wat regverdigheid en vroomheid oorskry (15.182).

Herodes se 'vergrieksing' van Jerusalem $(15.267,328)$ is 'n verdraaiing van Judaïsme en die oorsaak waarom die stad later vernietig is. Ook Herodes se grafskending — van Dawid se graf! — was 'n gruwel voor God en het God se wraak oor Herodes se familie gebring (16.179-188).

Josefus is nou ook bereid om uitvoerig Herodes se karakter vir ons uit te lê. Onder andere verduidelik hy dat diegene wat Herodes se karakter paradoksaal vind, hom net nie reg verstaan nie. Herodes is nie 'n kombinasie van vrymoedigheid en wreedheid nie. Nee, net een motief dryf hom, onbeteuelde gierigheid en ambisie. Herodes was 
net vrygewig wanneer dit ' $n$ middel tot 'n doel was; andersins is hy hard, onwrikbaar en boos. Herodes se aard staan in teenstelling tot die waardes van Judaïsme se wet en tradisie (16.150-159). Die koning het 'n 'ongodsdienstige gees', sy verstand kan boosheid nie uitlos nie (16.395-404). Die noodlot het wel 'n rol in sy lewe gespeel, en sy seuns het inderdaad bygedra tot die hele treurmare, maar op die ou eind is Herodes 'wreed teenoor een en almal, hy gee gewillig oor aan woede en hy minag regverdigheid

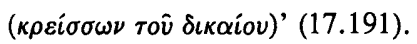

Die vraag is nou, bokant wie se geregtigheid (en geregtigheid vir wie) het Herodes hom nou geag?

Die Joodse Oudheidkunde wei in besonderhede uit hoe ellendig Herodes se uiteindelike siekbed was en skryf sy lyding toe aan sy godslastering (17.150-152) ${ }^{11}$. Hierdie moraliserende noot is deel van hierdie werk se tese dat die bose goddelike retribusie sal ontvang. Die hele lang verhaal oor Herodes se familie is relevant, so sê Josefus self, om aan te toon dat geen mate van wêreldse mag kan slaag as dit nie gepaardgaan met vroomheid teenoor God nie (18.128).

Die nodige kombinasie van vroomheid en mag is deel van die 'morele onderrig wat die mensdom moet ontvang'. Die 'bose', so kom ons geleidelik agter, is diegene wat nie die ou wette hou nie (soos Josefus die tekste uitlê, natuurlik) en goddelike waardes (wie besluit nou daaroor?) verraai. Ons, vandag, moet onsself afvra of dit gronde bied vir ' $n$ voldoende beoordeling van iemand.

Die vreemdheid van Josefus se logika mag nie onderskat word nie. Oor Agrippa 2 vertel Josefus dat, toe Agrippa 'n spele in Sesarea bygewoon het, hy klere gedra het wat geglinster het in die son. Trouens, so helder het dit geskitter dat sommiges van die adellikes Agrippa as goddelik aangeroep het. Omdat hy hulle nie dadelik tereg gewys het nie, is hy onmiddellik met 'n hartaanval geslaan wat vyf dae later fataal geblyk het (19.343-352). Diegene wat God se wette oortree word geslaan en geslaan.

\subsubsection{Vanwaar die verskille?}

Die standaard respons op hierdie verskille is tweërlei van aard. Eerstens word aangedui dat Josefus vir sy Joodse Oudheidkunde ander bronne gebruik het. Vir die Joodse Oorlog het hy gesteun op die verslae van Nikolaus van Damaskus, Herodes se sekretaris wat uiteraard gunstige gegewens oor Herodes nagelaat het ( $\mathrm{vgl} A J$ 16.184). Vir die Joodse Oudheidkunde het Josefus gesteun op 'verdere navorsing' (bykans 20 jaar skei die twee werke) en hy het op 'ander bronne' naas Herodes se $i \pi 0 \mu \nu \dot{\eta} \mu \alpha \tau \alpha$ afgekom (vgl 15.174) ${ }^{12}$. 
Tweedens word voorgestel dat Josefus se eie opvattinge verander het, wat hom of meer eerlik ó minder goedgunstig gestem het. Uiteraard is daar waarheid in albei redenasies. Die probleem is dat so 'n oplossing neig om die Joodse Oudheidkunde te sien as 'korreksie' en aanvulling van die vroeër werk. Maar is dit so eenvoudig?

Deel van die veranderde omstandighede is natuurlik dat die laaste van die Herodiane ten tye van die Joodse Oudheidkunde oorlede is en dus vir Josefus die ruimte laat om sy eie weergawe te gee. Josefus self was nie net 'n priester nie, maar ook 'n Hasmoneër ${ }^{13}$; 'n edelman dus wat adellike afkoms bewonder en waardeer. Johannes Hirkanus is sy groot held en Mariamme het hy bewonder oor haar voortreflike afkoms. Natuurlik sal dit 'n effek hê op hoe hy Herodes voorstel. 'Ons', so skryf hy:

is familie besonder na aan die Hasmonese konings en deel daarom in die priesterskap met eretitel, en beskou dit onvanpas om iets oor hulle vals voor te stel, maar beskryf hulle dade met eerlikheid en billikheid. Ons respekteer baie van (Herodes) se afstammelinge wat geheers het, maar ons ag waarheid belangriker as wat hulle het, en het selfs partykeer van hulle kwaad gemaak.

(Josefus, $A J$ 16.187)

Die bevredigendste antwoord is om te let op die oogmerke van die verskillende werke. Die oogmerke van die twee werke is uiteenlopend. Die Joodse Oudheidkunde wil wys dat goddelike oordeel onvermydelik volg wanneer mens afwyk van die wette van Moses - soos byvoorbeeld Herodes. In die Joodse Oorlog laat Josefus enkele kritiese opmerkings oor Herodes se ongeloof val (BJ 1.649-650; 2.84-86), maar hier gaan dit oor die regverdiging van politieke beleid en keuses.

Nogtans bly daar talle weersprekings en probleme oor. Josefus, soos bykans alle antieke bronne, is nie eenvoudig om te gebruik nie. Die Joodse Oudheidkunde is weliswaar langer as Joodse Oorlog, maar:

this does not appear to be due predominantly to additional information. Much of the longer work is marked by rhetorical embellishment and dramatic expansion, often referred to as 'novelistic elements': descriptions of the thoughts of the characters, additional dialogue and speech, expansion by means of inessential detail that may come from imagination rather than a greater knowledge, and Josephus's personal views.

(Grabbe 1992:316; vgl Smallwood 1976:100 n 140; Attridge 1984:212213) 
'n Aspek wat ook maklik buite rekening gelaat word is, weer eens die kwessie van antieke tekste se sosiale funksie. Josefus boots Dionisius se Romeinse Oudheidkunde na, sy teks is soortgelyk bedoel as 'high-minded entertainment', in Downing (1982: 558) se paslike beskrywing. Met Herodes se siekte, byvoorbeeld, krioel sy geslagsdele met wurms $(A J 17.169)$. Grant (1971:12) skryf:

As will become clear, however, when we come to the last phase of Herod's long life, the tale is not history but myth or folk-lore: a portentous symbol of the grip which one man's formidable personality exerted upon the imagination of his contemporaries.

\subsection{Assumptio Mosis}

Die Testament van Moses is ' $\mathrm{n}$ apokaliptiese teks waarin die verteller, met die oortuiging dat hy in die laaste dae leef, Moses se profesieë (Deut 28-34) toepas op 'Israel' se geskiedenis. Die teks is duidelik 'n samestelling wat veroorsaak dat verskillende daterings aan die dokument gekoppel word (vgl Priest 1983:920-921). Die oortuigendste verklaring vir my is die teorie van Nickelsburg $(1987: 80,213)$ waarvolgens hoofstukke 6-7 sekondêr tot die oorspronklike werk wat tydens Antiogus Epifanes se regeertyd ontstaan het, bygevoeg is om-en-by die tweede dekade van die eerste eeu ${ }^{14}$.

Die gemeenskapstrajek van hierdie teks is baie onduidelik. Ons kan vandag nie meer die ideologie van die groep wat hierdie teks bewaar en kosbaar beskou het, identifiseer nie. Die tempel is baie prominent en belangrik, maar daar is nie ' $n$ militante motief (soos in 1 Hen 83-90) of 'n oproep tot stryd met onregverdige Judeërs nie. Dit lyk asof dit 'n groep priesters was wat om een of ander rede ' $n$ vervreemding van die bestaande tempelhiërargie ervaar het wat hierdie tradisies bewaar en gebruik het. Mens kan wel die bekende polemiek teen die Jerusalemse priesterdom (vgl bv 1 Hen 12-16, PsSal 8.13, CD 5.6-7) herken. Die gedeelte wat waarskynlik op Herodes betrekking het, lees soos volg:

... a wanton king, who will not be of a priestly family, will follow them. He will be a man rash and perverse, and he will judge them as they deserve. He will shatter their leaders with the sword and he will (exterminate them) in secret places so that no one will know where their bodies are. He will kill both old and young, showing mercy to none.

Then fear of him will be heaped upon them in their land, and for thirty-four years he will impose judgments upon them as did the Egyptians, and he will punish them. And he will beget heirs who will reign after him for shorter periods of time. 
After his death there will come into their land a powerful king from the West who will subdue them; and he will take away captives, and a part of their temple he will burn with fire. He will crucify some of them around their city.

(TMos 6.2-9; Priest 1983:930)

Dit is veral die verwysing na 34 jaar wat mens laat vermoed dat Herodes hier ter sprake is (as mens Herodes se heerskappy tel vanaf 37-4 v C, vgl Josefus $A J 17.191$ ). Hoe 'n apokaliptiese teks vir historiese verstaan gebruik moet word, is natuurlik 'n ope vraag. 'Precise historical details need not be expected in an apocalyptic writing' is Priest (1983:930) se waarskuwing. Ons het hier die neerslag van 'n mondelinge tradisie wat oorvertel is deur mense wat wel vyandig teenoor Herodes blyk te wees, maar veral wil beklemtoon dat God sondes straf. Dit wil sê, Herodes mag wel goddeloos wees, maar eintlik voer hy God se regmatige wil uit. Die klem is duidelik daarop dat die volk heeltemal verdien dat Herodes hulle so uitmoor.

Diegene wat dus deurgeloop het, sou dinge nie anders gehad het as die vertellers 'n groot sê gehad het nie. Verder wys die onderskeie beskrywings net weer die probleem van perspektief uit. Wie is die 'volk' wat so verdeeld is, en waarom is die 'ander deel' so sondig en halsstarrig? Hoekom moet die koning 'n priester wees? Sou dit hom 'n beter koning gemaak het? 'Rash and perverse' is soortgelyke waardeoordele wat gekoppel is aan ' $n$ perspektief.

Daar is heelwat suggesties dat die ander diegene is wat 'n meer Hellenistiese oriëntering het, byvoorbeeld: 'they will pollute the house of their worship with the customs of the nations; and they will play the harlot after foreign gods' (TMOs 5.2). Ons het hier 'n konflik tussen verkramptes en verligtes (en die implikasies vir historiese konstruksie is allermins eenduidig).

\subsection{Ander verwysings}

Josefus is natuurlik nie die enigste antieke skrywer wat eksplisiet na Herodes verwys nie (Otto 1913:2-15; Grabbe 1992:314-320). In die Talmoed is daar besonder min opmerkings oor Herodes, bo-en-behalwe dat hy 'n voortreflike duiweboer was en dat die tempel wat deur hom opgebou is, wonderlik was (vgl b. Baba Batra 4a). 'Talmudic tradition obviously tries to make out that Herod was an ephemeral phenomenon in the history of the second Temple, who disappeared from the scene of his activity leaving no trace behind him' (Schalit 1971:36). Die redes hiervoor en ook die implikasies vir die verstaan van Herodes is onbekend. 
In die klassieke tekste is daar nogal heelwat verwysings na Herodes, maar dit is gewoonlik terloops en te kort om iets van te maak (bv Takitus Hist 5.9; Appianus Bella Civilia 5.75). Die meeste van hierdie opmerkings is neutraal (bv Filo Legatio ad Gaium 37.294-297). Ander is positief, soos Persius (Saturea 6.179-183) wat laat blyk dat Herodes besonder gewild in die Diaspora was.

\subsection{Die sinoptiese evangelies}

\subsubsection{Matteus 2}

Dit is ironies dat die teks wat maklik die minste histories is, die grootste rol gespeel het in die vorming van die algemene opvatting oor Herodes ${ }^{15}$.

Hierdie verhaal is kennelik legendaries (folklore). Problematies is die ster wat onbekend in Judea bly totdat die magiërs navraag doen, en eers dan ontdek nie net hulle nie, maar ook Herodes dat die Messias gebore is. Herodes stuur nie eens ' $n$ spioen of 'n gesant saam met die hoogwaardigheidsbekleërs nie. Let ook op dat die hele Jerusalem $\left(\pi \hat{\alpha} \sigma \alpha \ldots \mu \varepsilon \tau^{\prime} \alpha \dot{v} \tau o \hat{v}\right)$ saam met Herodes ontsteld is: Matteus stel Jerusalem op as Jesus se teenstelling, en hiervoor dien Herodes ook sommer. Jerusalem, Herodes, 'al die hoëpriesters en skrifgeleerdes' is saam 'n kode hier: 'to range Jerusalem alongside Herod as the center of antagonism toward Jesus and of later persecution against the church' (Gundry 1982:28).

Twee studies wat doelbewus uitgesoek is as nie die produkte van die wêreld se radikaalste eksegete nie, bied ' $n$ raamwerk om die verhaal te beoordeel.

Gundry (1982:26-41) sien die verhaal as Matteus se kreatiewe manipulasie van tradisie om 'n parallel tussen Jesus en Moses te trek. Matteus speel die illegitieme koningskap van Herodes af teen die legitieme aanspraak van Jesus, die koning van die Judeërs (Gundry 1982:31). 'Matthew is making Jesus the greater Moses just as he has already made him the greater David' (Gundry 1982:33). Dit is hierdie Moses-tipologie wat ten grondslag lê van die berugte kindermoord in Betlehem (Gundry 1982:34-35): 'Herod's massive crimes made it easy for Matthew to manipulate the dominical tradition in this way'. Gundry beklemtoon dat dit gaan oor die 'boodskap', die Christologie van Matteus, die aanklag teen 'Joodse leiers' en die uitwys van die 'dreadful consequences of rejecting Jesus'.

It may be asked how Matthew can put forward his embellishments of tradition as fulfillments of the Old Testament. But this phenomenon should surprise us no more than his transforming historical statements in the Old Testament ... into messianic prophecies. We will have to 
broaden our understanding of 'happened' as well as of 'fulfilled' when reading that such-and-such happened in order that so-and-so's prophecy might be fulfilled.

(Gundry 1982:37)

Luz (1985:115) beskryf die betrokke berig as 'eine knapp und nüchtern erzählte Legende, die nicht nach den Gesetzen historischer Wahrscheinlichkeit fragt'. Hy behandel die talle parallelle met hierdie stories en som op:

Kurz, ein historischer Kern ist nicht mehr greifbar; hingegen machen die zahlreichen Parallelüberlieferungen in der Religionsgeschichte die Ausgestaltung der Geschichte verständlicher.

(Luz 1985:116)

Luz (1985:119) stel dan die implikasie van historisiteit minstens eerlik deur te vra hoe 'n onhistoriese verhaal kan geld vir teologie en etiek. Die ander vraag is natuurlik hoekom 'n fiktiewe verhaal so beslissend geword het vir die beoordeling van Herodes.

Ekself beskou hierdie verhaal, op die beste geneem, as gebaseer op 'n politieke gerug wat in die sestigerjare ontstaan het (Botha 1993). Maar in die lig van die wydverspreide voorkoms van gelyksoortige stories oor koningskinders in die antieke wêreld, is Matteus 2 waarskynlik 'n volksverhaal (folktale). Dit wil sê, 'n dramatiese storie met 'n bekende vorm wat hoofsaaklik 'n mondelinge tradisie-agtergrond en ontstaan het. Die betekenis van sodanige stories lê in die verhouding tussen die storiebeelde (tale images) en sosiale en psigologiese werklikhede, en die gevolglike gemeenskapsfunksies van die vertelling (kyk Fischer 1963).

Hierdie verhaal het waarskynlik as 'n wens-vervulling gefunksioneer, en is waarskynlik oorvertel in kringe wat bedreigd gevoel en minderwaardigheidsgevoelens ervaar het (irrelevant van die reële bedreiging). Die historiese verdraaiing is 'n uitdrukking van wense en behoefte aan waarde. In die tegniese literatuur word so 'n verhaal beskryf as 'n 'evaluative compromise formation': 'n Storie wat 'n kompromie met die werklikheid aangaan ter wille van die groep/verteller se konstruksie van subjektiewe integriteit (Fischer 1963:264).

\subsubsection{Lukas 1.5}

Lukas 1.5 is baie algemeen: Johannes die Doper is waarskynlik ten tye van Herodes se regering gebore. Die probleme word deur Luk 2:1-2 geskep: Herodes, die tyd wat 
nodig is vir Elisabet en Maria se swangerskappe om te oorvleuel (1:41) en die volkstelling kan nie in 'n realistiese kronologiese raamwerk ingepas word nie. Vir Lukas is dit myns insiens belangrik om Jesus aan die sensus van die Siriese goewerneur te koppel. Die rede is moontlik Lukas se politieke interesse: Die impak van die gebeure rondom Judas van Galilea (BJ 2.117-118, $A J$ 18.1-10) behoort in 'Christologiese' lig gesien te word. Dié gebeure het na Herodes se leeftyd plaasgevind, en Lukas is nie baie goed ingelig oor die presiese daterings nie (vgl Fitzmyer 1981:399-405).

\section{PERSPEKTIEF OP HERODES DIE GROTE}

Wat doen 'n koning? Josefus vertel meesal net van die sensasionele, ongewone dinge. Wat die alledaagse dagtaak van 'n koning betref, weet almal mos wat dit behels ....

Millar (1967:9) herinner ons aan iets wat met Hadrianus gebeur het toe 'n vrou hom wou voorkeer (Dio 69.6.3). Die keiser het nie tyd nie en ignoreer haar. Kaì $\mu \grave{\eta}$ $\beta \alpha \sigma i \hat{\lambda} \varepsilon v \varepsilon$ skreeu sy agter hom aan. Wat Millar oor die keiserlike ideologie skryf, geld ook van 'n vasalkoning: hy is 'personally accessible to his subjects in a way which now seems incredible, and which most books on the Empire tend to ignore, or regard as trivial' (Millar 1967:9) ${ }^{16}$.

Dit is te oorvereenvoudig om Herodes te beskuldig van 'n outokratiese regeerstyl. Hy was 'n koning en het opgetree soos 'n koning. So het sy onderdane hom gesien en van hom verwag om soos ' $n$ koning op te tree. Die alternatief was net ' $n$ ander koning of 'n verteenwoordiger van die Romeinse keiser, wat soos 'n koning sou gemaak het. Verder bring verkenning van Josefus se geskrifte ondubbelsinnig by mens tuis dat dit ' $n$ vreemde, ander wêreld was.

Administrative history has peculiar dangers of its own. We all know that we do not understand Roman religion. Administration seems easier, more readily comprehensible in present-day terms. Hence the evidence can be confidently distorted to fit entirely anachronistic concepts.

(Millar 1967:9)

Dit is, gegewe die vyandige tradisies oor Herodes, opvallend dat naas sy strengheid ook sy vrygewigheid beklemtoon word. Hy het ook groot waarde daaraan geheg om die 'mense' (die 'volk' soos Josefus sal sê) direk toe te spreek (veral in die stede Jerusalem en Jerigo). Sulke volksbyeenkomste ( $\dot{\varepsilon} \kappa \kappa \lambda \eta \sigma i \alpha, \pi \alpha \dot{\alpha} \nu \delta \eta \mu \varsigma)$ is natuurlik 'n effektiewe manier om jou eie propaganda te versprei, naas die vanselfsprekende geleentheid om informasie aan te kondig. In $14 \vee \dot{C}$, byvoorbeeld, het Herodes by so 'n geleentheid 
die afloop van sy reis na Klein-Asië verduidelik (na die gewone ophemeling van sy eie regering ensovoorts), hoeveel sukses hy behaal het met die verdediging van Joodse regte, asook 'n $25 \%$ afslag vir die jaar se belasting ( $A J$ 16.62-65). Dit is nodeloos om te herhaal dat Josefus meld dat die koning geloof is deur die blymoedige skare (vgl 15.381).

Herodes het streng opgetree teen die verskynsel van 'people's courts'. Sodanige verskynsels het meesal ontaard in lynching mobs en Herodes het telkens ingegryp met die opdrag dat ' $n$ verhoor moet plaasvind. Ook met betrekking tot die moeilikhede met sy gesin het Herodes telkens 'n verhoor laat plaasvind.

Uiteraard het die koning ' $n$ uitgebreide burokrasie gehad om hom by te staan, en in Judea/Jerusalem ook nog die Sanhedrin ${ }^{17}$. Maar onthou, die instansies het net gesag vir sover as wat die koning dit ondersteun. Dit beteken dat hy persoonlik verantwoordelik was vir alle besluite en aktiwiteit op 'n wyse wat vandag ongelooflik lyk. Dink net aan die eindelose stroom prosedeerders en verweerders, versoeke, delegasies, aansoeke ensomeer.

'n Wetgewing wat Josefus wel geïnteresseer het, was Herodes se aksie teen diewe (AJ 16.1-5). In 'n 'ernstige' strewe om ongeregtigheid ( $\alpha \delta \iota \kappa i \alpha \varsigma)$ in die stede en op die platteland te bekamp, het Herodes 'n wet gemaak dat diewe wat gevang word as slawe buite Palestina verkoop moes word ${ }^{18}$. Die Joodse gebruik het natuurlik die rykes gepas ('n goedkoop bron van slawe) en het duidelik nie goed gewerk as afskrikmiddel nie. Josefus sien in Herodes se streng wette sy minagting vir die 'ou gebruike' en lei daaruit sy gebrek aan vroomheid af. Die probleme van beoordeling is duidelik. Josefus beskou Herodes se wet as "'n oortreding teen godsdiens eerder as 'n straf vir die wat

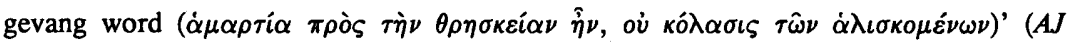
16.2). En let op, slawerny as sulks is vir almal aanvaarbaar, solank 'n Jood net nie aan 'n heiden verkoop word nie.

Ons moet in gedagte hou dat die koning destyds letterlik 'die redder van die mense' was (dit is die kulturele waarde wat tot uitdrukking kom in die titel $\dot{o}$

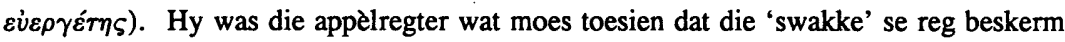
word. Daar was geen onafhanklike polisiemag of regstelsel nie. As jou buurman jou moeilikheid gegee het, en jy oorleef dit, kon jy net na die koning toe hardloop en hoop dat hy bereid sou wees om jou probleme oor te neem. Verder moes jy sorg dat jy 'n uitgebreide netwerk van onderdane (clients) en minstens een sterk beskermheer (patron) het, want sou jy dit nie maak wanneer jy moeilikheid optel nie, was hulle jou enigste hoop om jou belange, familie en erfenis te beskerm.

Wat die detail van Herodes se regering betref, weet ons bitter min. Ons weet dat hy populêr by die 'mense' was (selfs, teësinnig, volgens die Joodse Oudheidkunde), en dat hy lank geregeer het. Bokant die vasalkoning het die keiser gestaan, en dié was daar (teoreties minstens) vir elke burger, en selfs enige onderdaan kon 'n petisie aan 
hom rig. Soos talle konings na Herodes wel deeglik uitgevind het! Dit is ook onvoorstelbaar dat ' $n$ vyandige bron soos die Joodse Oudheidkunde sou nalaat om te beklemtoon dat Herodes lui was, weggekruip het vir hofsake, nie korrespondensie geantwoord het nie, of mense laat wag het nie (vgl Millar 1967:18)

Joodse tradisie is beroemd vir die sogenaamde klem op die arme. Maar dit is juis Herodes se "welfare measure, which took no account of knowledge or ignorance of the Law' (Grant 1971:123) wat hom groot roem gebring het. Tydens $25 \vee \mathrm{C}$, byvoorbeeld, was daar ' $n$ besonder strawwe droogte. Herodes het vanuit sy eie sak betaal vir die ondersteuningsdienste asook vir die ingevoerde graan (vanaf Egipte - goeie internasionale betrekkinge het sy voordele!).

\subsection{Verdrukking}

\subsubsection{Gerugte en die probleem van betroubare inligting}

Antieke kommunikasie verstaan as antieke kommunikasie behoort 'n verreikende impak te maak op ons perspektiewe en dus op die verstaan van die destydse wêreld (Botha 1990, 1992b).

Gerugte speel 'n geweldige rol (soos by ons ook maar) in pre-industriële samelewings (cf Botha 1993). Virgilius (Aen 4.173-197) beskryf 'n gerug (fama) as die snelste van alle euwels, 'n onkeerbare monster wat waarheid verswelg en mense vernietig. Josefus se verhale laat telkens blyk hoe verreikend en hoe omvattend gebeure destyds deur gerugte bepaal is (bv, maar daar is baie, baie gevalle, $B J 1.258,371 ; A J 15.71$, 17.51). Herodes het voortdurend met gerugte te doen gehad. Hoe het 'n mens destyds korrekte inligting verkry en versprei? Daar was nie massamedia nie. Die enigste manier was om deứr middel van 'n persoonlike netwerk te opereer. Met ander woorde, Herodes se inligtingsdiens moet nie noodwendig gelees word as 'n 'big brother' nie19 - alhoewel hy sekerlik die geleentheid vir persoonlike gewin gebruik het - maar as 'n stelsel van 'informasie' versprei.

Tweedens: outentieke dokumentasie. Hoe moes Herodes bepaal het of getuienis betroubaar is - of omgekeerd, hoe kon mens 'n vervalsing bewys? Destyds het by verre die meerderheid mense nie self geskryf nie (vgl Botha 1992a). As Herodes dus op 'getuienis' afkom, soos Aleksander se brief (AJ 16.318), of Mariamme se boodskappe, wat het hom dan te doen gestaan? Hy het, soos mens destyds gemaak het, die slawe gemartel om die waarheid (letterlik) uit te trek; mense ondervra en toetse gedoen (soos die befaamde liefdesdrankie vir ' $n$ veroordeelde te voer). En hy het sy saak voor ander gestel, waartydens die beskuldigdes ook geleentheid gekry het om húlle saak te stel. 'n Voorbeeld hiervan is die moeilikheid met Antipater (BJ 1.618-646), waartydens Herodes, vir soverre ons Josefus kan vertrou, 'n aangrypende toespraak hou.

En dan het Herodes opgetree .... 


\subsubsection{Belasting uitbuiting}

Dit is ' $n$ gemeenplaas om te sê dat Herodes swaar belastings gehef het. Maar gemeet waaraan? Betaal ons almal nie nog altyd te veel nie? Josefus weerspreek homself hieroor. Hy vertel dat na Herodes se dood is daar gekla oor die hoë belastings (deur die ryk grondbesitters natuurlik, wie anders word effektief belas?), maar in sy verhaal self beklemtoon hy Herodes se vrygewigheid. Dit sou selfs nie moontlik wees om al die

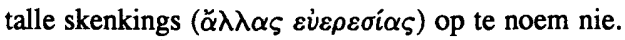

Ons weet dat Herodes se totale belastings uitwerk op 1050 talente per jaar ( $A J$ 17.317-320), maar wat ons daarvan moet maak is moeilik om te sê. Dit is, relatief gesproke, aansienlik minder as Egipte se belastingtotaal, en ook minder as wat Agrippa 1 ingesamel het tydens sy regeertyd (vanuit 'n kleiner landgebied, $A J$ 19.352). Verder moet die kwarteeu wat die Herodiaanse tydperk voorafgegaan het (die era sedert Pompejus) as konteks in berekening gebring word. In die tydperk het Palestina ekonomies besonder swaar geleef as gevolg van verskeie strafbelastings wat deur die Romeine geëis is (Grabbe 1992:335). Onder Herodes was Judea nie skatpligtig (tribuut) teenoor Rome nie (Braund 1984:66, Grabbe 1992:337).

Herodes het 'n hoofbelasting ingestel (met 'n sensus elke 6 jaar soos die bekende Ptolemese burokrasie?), maar ook grondbelasting wat ingesamel is as graan wat in openbare skure geberg is. Verder is 'n eiendomsbelasting asook - indien ons Josefus reg verstaan - 'n soort van verkoopbelasting gehef.

Waarskynlik is 'n deel van die kostes verbonde aan die heropbou van die tempel gefinansier met behulp van die diaspora tempelbelasting (Broshi 1987:34-36), alhoewel Herodes daarop aanspraak gemaak het dat hy self vir die opbou van die tempel betaal het $(A J 17.162)^{20}$.

Ongetwyfeld was daar grootskaalse ekonomiese opheffing tydens Herodes se regeertyd (Broshi 1987:31-33). 'n Uiters suksesvolle hawe is ontwikkel en die talle bouwerke het nie sonder rede vir Herodes roem gebring wat tot vandag toe weerklink nie. 'The evidence, in so far as it exists, adds up to a picture of efficiency, but by no means of oppression' (Grant 1971:172).

Selfs wat die landvolk (peasants) betref, is dit waarskynlik so dat hulle beter daaraan toe was aan die einde van sy regeertyd as aan die begin. Schalit (1969a:322328) wys op die wydverspreidheid van die welvaart in hierdie tyd. Dit is belangrik dat die komplekse sosiale prosesse wat met verloop van tyd uitgeloop het op die tragiese konflikte van 60-70 nie op Herodes se era teruggeprojekteer word nie. Ons moet ook nie summier terme gebruik om disparate groepe saam te beskryf nie. Daar is verskeie aanduidings dat Herodes pertinent minstens dele van die landvolk bevoordeel het (Gihon 1967; Stern 1974:261). 


\subsubsection{Die moordlustige tiran}

'n Mens kan nie ontkom aan die indruk dat, as dit nie was vir Herodes se droewige familietwiste 21 nie, hy waarskynlik 'n veel positiewer beeld in die literêre tradisie sou

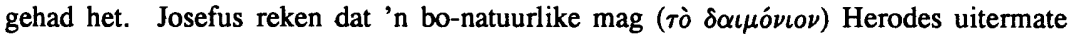
voorspoed in sy loopbaan $(\tau \hat{\omega} \nu \check{\varepsilon} \xi \omega \theta \varepsilon \nu)$ gebring het, meer as wat Herodes voor gehoop het. Maar dan moet mens wonder, vra Josefus, of dit reg is om sulke goeie geluk in publieke sake te hê teen die prys van huishoudelike smart, of om eerder sulke huislike tragedies te vermy deur sy wonderbaarlike sukses as koning prys te gegee het ( $A J$ 16.77).

Dat 'n hele klomp koppe gerol het onder koning Herodes se regering kan nie betwyfel word nie. Dit wás 'n genadelose, harde, tirannieke wêreld; 'n tydsgees wat die beste wil ter wêreld nie kan romantiseer nie en 'n soort politiek wat ons net kan en moet afkeer. Dit gaan vir my oor die raamwerk waarmee ons baie van hierdie bloedvergieting lees. Dat ons Herodes nie sommer lukraak moet beoordeel aan die hand van die heelwat 'anti-Herodian nonsense' (Smallwood 1981:426 n 19) waaroor ons beskik nie, word duidelik as ons 'n paar gevalle van opposisie teen Herodes bekyk.

In sy stryd teen die bandits van Galilea, tydens die konflik tussen Herodes en Antigonus, het van hierdie bendes in grotte geskuil (BJ 1.309-314, $A J 14.429-430)$. In 'n poging om sommiges se lewens te red, bied Herodes aan om die wat oorgee, te spaar.

Een man, vader van sewe seuns, is deur sy vrou en kinders gesmeek om te mag uitgaan omdat hulle lewens gewaarborg is. Die man se reaksie was soos volg. Soos wat hy hulle een vir een uitgeroep het terwyl hy by die grotopening gestaan het, het hy hulle doodgemaak. Herodes, wat alles goed kon sien, was hartverskeurd, en het sy hand uitgereik na die ou man en hom gesmeek om die kinders te spaar. Die man het die voorstel verwerp, Herodes uitgeskel as iemand van lae afkoms, en nadat hy die laaste van sy seuns en sy vrou doodgemaak het, het hy hulle liggame die afgrond afgegooi en self daar afgespring.

(BJ 1.314)

Ons hoef sekerlik nie so 'n gesigspunt as normatief te beskou nie. Dieselfde probleem sien ons ook met die 'groep van tien' wat beplan het om Herodes in die teater te vermoor. Die konteks is die befaamde trofee wat beskou is as beelde van mense

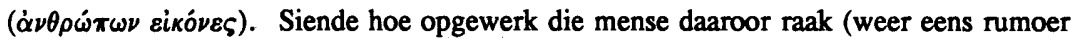
van dinge en gerugte van dinge), het Herodes die vooraanstaande beswaardes na die 
teater genooi en die 'beelde' vir hulle gewys ( $\delta \varepsilon i \xi \alpha \varsigma \tau \grave{\alpha} \tau \rho o ́ \pi \alpha \iota \alpha)$. Onmiddellik was daar 'n gelag, want dit was net houtstukke ( $A J$ 15.277-279). 'n Groep van tien mans was egter nie gerus nie en oortuig dat dit net die begin van groot euwels was en dat Herodes die vyand van die volk was. Hulle besluit toe om Herodes te vermoor, of dan minstens baie van sy mense ( $A J$ 15.281-285). Die komplot is egter deur een van Herodes se speurders ontdek en die manne is verhoor en tereggestel ( $A J$ 15.285-291). Hulle verweer was dat alle mense die plig het om hulle ou gebruike te beskerm of om daarvoor te sterf.

\subsection{Die ongelowige heiden}

Hoe sal ons kan weet? Herodes is besny en het groot geword as 'n 'Judeër'. Hy het 'n groot aandeel gehad in die heropbou van die Tweede Tempel ${ }^{22}$. Daar is baie getuienis dat hy homself as 'n Judeër beskou het: Sy muntstukke het geen menslike afbeeldinge nie (Meshorer 1967:127-129; Schürer, Vermes \& Millar 1973:296 n 24) en daar is ook geen spoor van menslike figure in die argeologiese oorblyfsels van Herodes se geboue nie. Trouens, sy bouwerke 'show a complex form of piety - but a piety which goes beyond what is acceptable in Judaism - and a concern for Torah that attempts to work within its limitations as he understood them' (Richardson 1986:347). Vir iemand wat by sy familie wou introu het hy besnydenis as voorwaarde gestel $(A J 16.225)$. Hy het ook goeie betrekkinge met die 'Fariseërs' gehandhaaf, en sy bewondering vir die Esseners (AJ 15.371-379) is welbekend. Hy het ook ongetwyfeld Griekse en Romeinse kulturele waardes bevorder.

Ek kry die indruk dat hy nie bygelowig was nie. Tydens die lente van 31 v C het 'n geweldige aardbewing Palestina getref. Josefus vertel (BJ 1.370) dat ontelbare beeste en 30000 mense gesterf het. Die Arabiere, aangehits deur 'n gerug dat Judea oop lê, reg vir oorname, het die Judese afvaardiging by hulle vermoor en opgeruk. Alles het verlore gelyk vir die 'mense'. Herodes spreek hulle toe:

Niemand kan daarop reken dat toeval of geluk vir altyd sal aanhou nie; almal weet hoe lukraak die noodlot is .... Verder, julle hoef nie 'n oog te knip oor die opskuddings in die wêreld nie, of julle te verbeel dat die aardbewing ' $n$ waarskuwing is van nog rampe wat kom nie.

Hoekom sou hy nie ernstig en toegewyd gewees het aan sy oortuigings nie? Herodes self (vir sover ons Josefus kan vertrou) sê dat hy deur die wil van God ( $\tau \hat{n}$ tôे $\theta \varepsilon o \hat{v}$ $\beta o v \lambda \dot{\eta} \sigma \varepsilon l)$ aan die Joodse mense ( $\check{\varepsilon} \theta \nu \circ \varsigma)$ voorspoed en rykdom gebring het soos nog 
nooit van tevore nie $(A J 15.383)$. Hy is koning, omdat God dit gewil het ( $A J 15.387)$ - alledaagse uitsprake weliswaar, maar moontlik ook met erns verklaar. Op 'n stadium het hy gesê: 'Ek het God met soveel toewyding gedien dat ek mag hoop op 'n baie lang lewe' (BJ 1.462).

Hy hét deelgeneem aan die keiserkultus - maar die logika daarvan is nie vreemder as die van die offerdiens in die Jerusalem tempel nie. Waarskynlik is daar meer agter Herodes se 'oppervlakkigheid' as wat baie wil toegee. 'The apparent ambivalence of Herod's policy surely attests his deep insight into the problem of Jewish-Gentile relations. He shared Augustus' aim to unify the peoples of the Empire in a common culture .... Herod's policy was sagacious and farsighted' (Brandon 1969:220). Dit is baie soos Paulus 'n paar dekades later sou redeneer (1 Kor 9.19-23).

Ons moet onthou dat Josefus 'n konserwatiewe priester/Fariseër was. Die tempel was vir hom van die uiterste belang; hy moes nou kon verduidelik hoekom God teen sy 'volk' gedraai het en waarom die tempel van God verwoes is. En dit was maklik, want daar was so baie sondebokke.

\subsection{Perspektief}

Op 2 Januarie 1992 het F W de Klerk in Suid-Afrika 'n proses van magsoordrag in werking gestel. Hoe moet hierdie proses voorgestel word? Die Konserwatiewe Party (en Afrikaner Weerstandsbeweging) sien heeltemal tereg hierin ' $n$ vermindering van die mag van 'n sekere groep. Vanuit hulle perspektief is die proses sleg, 'n aantasting van vryheid, 'n verraadskomplot ensovoorts. Andere, ook in hierdie land, reken dat die proses die voortreflikste gebeurtenis van dié eeu is. Sou net een groep se geskrifte (en dan nog net ' $n$ deel van daardies) behoue bly, is die implikasie vir toekomstige geskiedskrywing duidelik.

Dit is egter nie net die bronne wat 'n probleem is nie. 'Herod has been such a notorious and controversial figure that any evaluation of him is very difficult. One must consider against what standard his reign is to be assessed: Other Greco-Roman despots? The Hasmonean rulers? Some golden ideal of kingship?' (Grabbe 1992:362).

Herodes het ongetwyfeld die tradisionele hoëpriesterlike kringe se mag gebreek. Maar met watter perspektief moet ons die gebeure lees? Josefus, self 'n priester, het gevoel dat dit ' $n$ baie negatiewe ontwikkeling was.

Herodes het homself nooit 'die Grote' genoem nie - vir sover ons weet in elk geval. Ook nie Josefus nie - hy praat gewoon van die koning, of verwys na Herodes. Slegs eenmaal noem hy hom $\dot{o} \mu \varepsilon \dot{\gamma} \alpha \varsigma$ ( $A J 18.130$ ) om hom te onderskei van sy nakomelinge. Dit is maar net 'n naam; wie sou só 'n titel kon verdien? Op gronde waarvan? 
Dit is sekerlik duidelik dat, al was hy 'n verskriklike mens, ons heeltemal te min van hom weet. Ons weet nie wat hom gedryf het nie en ons weet nie presies wat meesal gebeur het nie.

Daar was teenstand teen Herodes, maar ons moet daardie teenstand éérs verstaan en die groep (of groepe) sosio-ekonomies en kultuur-ideologies kan plaas om die konflik te interpreteer en reg aan die verskillende partye te laat geskied. Herodes se regeerstyl het ongetwyfeld die 'retainer' en 'artisan' klasse bevoordeel, ten koste van die tradisionele aristokrasie. Húlle persepsie is nie noodwendig die beste maatstaf waarmee ons moet meet nie. Verder het Herodes die Diaspora Jodedom baie sterk ondersteun en hulle belange in Jerusalem en Palestina bevorder (kyk Grant 1971:178182; Stern 1974:273-275 vir samevattings) — 'n verdere steen des aanstoots vir die tradisionele Judese aristokrasie.

Ons eie ideale speel baie subtiel, maar tog baie deeglik, 'n rol in interpretasie. Jones, byvoorbeeld, skryf baie onwillig oor die geweld in Grieks-Romeinse spele; dit is immers 'alien to the true spirit of Hellenic culture' (1938:95). Maar juis so gesien kan Jones' vir Herodes verwyt oor sy deelname daaraan. Soortgelyk Perowne (1956:179180) wat weet wat die 'spiritual destiny' van 'Jewry' is (die Christendom natuurlik) en Herodes verkwalik omdat hy nie 'the signs of the coming of the new dispensation' kon raaksien nie. Dit wat ons admireer, word al te maklik 'die werklike essensie' van iets in die verlede. Dan neem ons aan almal weet wat dit is, beter as ons bronne en ongetwyfeld beter as Herodes 23 . So is dit moontlik om hom of hulle af te kraak. In ons afkeure wys ons ook ons voorkeure, maar ons moet net bietjie dink. Partykeer is hierdie voorkeure net bevooroordeeld, of lukraak, of selfs vernederend vir andere.

Ons is vandag (gelukkig!) baie bewus van anti-Joodse gevoelens, maar wat van anti-heidense oortuigings onder die Judeërs? Josefus vertel nogal die een en ander insident van sulke gevoelens. Is Herodes 'anti-Joods' of 'pro-heidens'? Is sy strewe om Judea deel te maak van die groter, 'moderne' wêreld slegte beleid? Stern (1974:248) neem Herodes kwalik omdat sy 'subjects were de facto without rights'. Gegewe egter die realiteit van die Romeinse Ryk, waar en hoe sou de facto regte moontlik gewees het? Grant (1971:13) het 'n veel beter vertrekpunt:

... the real problem raised by the career of Herod should be framed in rather different terms: how is it possible for a small country to reconcile its own special, peculiar way of life with a sufficient degree of conformity to the requirements of a super-power. 
En wat Herodes se 'quite unscrupulous in cultivating friendships with anyone of importance', 'ingratiating himself with whoever replaced them' (Schalit 1971:38) betref: die stelsel van inkruip was hoe daar destyds geleef is. Sonder patrons en clients het jy baie gou ondergegaan. Mens sou kon sê dit was die wet wat alles bepaal het. Herodes was net slim genoeg om nie die verkeerde patrons uit te soek nie.

\title{
5. WAT MAAK DIT SAAK?
}

Is dit die moeite werd om meer te weet van Herodes? Dis nou bo-en-behalwe die insig dat tien vrouens duidelik moeilikheid soek is.

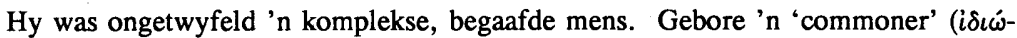
$\tau \eta \varsigma, B J 1.665$ ) - iets wat Josefus, terloops, hom nie kon vergewe nie - het hy dit reg gekry om die hoogste sport van sy samelewing te bereik. Hy het oorleef in die moorddadige wedywering wat sy wêreld gekenmerk het. Hy het ongekende voorspoed vir Palestina bewerkstellig, vrede vir drie dekades, en die Romeinse tribuut weggehou. Die belangrike is egter nie om te kan sê só of só was Herodes regtig gewees nie. Nee, die belangrike is dat ons onsself leer ken. Die oefening word die moeite werd wanneer mens besef dat ons moet vra: Waarmee sal ons wat beoordeel? Ons het immers te doen met ander, wat ons nie maar net na willekeur kan laat buikspreek nie. Soos Bauman (1992:200-201) sy mede-sosioloë tereg wys:

\begin{abstract}
Their dissimilarity [cultural diversity] was not conceived as the testimony of the relativity of all and any cultural superiority; rather, their 'imperfections' were seen as living proof of the advantages of the pattern defined as ideal. The evaluating posture had, so to speak, an inbuilt self-corroborating mechanism. It could remain immune to the mere accumulating of knowledge of cultural variety, as long as the structure of social dominance which underlied it remained intact and unassailed.
\end{abstract}

Nee wat: die waardige strewe lê opgesluit, in Bauman (1992:194-224) se treffende frase, understanding as expansion of the form of life. 'n Nie-hermeneutiese geskiedskrywing is eintlik ' $n$ ontkenning van onbegrip (incomprehension). In plaas daarvan om met andersheid gekonfronteer te word en die perke van huidige insig te besef, lees ons alte gou netjies verpakte, klaar gemaakte propaganda.

Daar is skurke en helde, maar selde is een mens net een. Die sukses van die poging om te vra wie en wat Herodes was, is om uit te kom by vrae soos: wanneer is iets reg en wanneer verkeerd? Wie sê watter optrede is neerdrukkend vir wie? Hoekom word dinge op sekere maniere gedoen? 
Ons verdoem gou (en tereg ook) die feit dat Herodes mense gemartel het. Maar óns vraag behoort eerder te wees: hoekom is mense gemartel. Mense word gemartel in die geloof dat waarheid dáár is, dit moet net gevind word, selfs al moet dit met geweld uitgetrek (of uitgeslaan word). 'The very idea of truth we receive from the Greeks ... is inextricably linked with the practice of torture, which has almost always been the ultimate attempt to discover a secret "always out of reach"' (DuBois 1991:7). 'n Ander vraag waarmee Herodes my konfronteer, is sy oortuiging - net soos sy opponente s'n - dat God aan mense onveranderlike, onaantasbare regte gee. En by hierdie - en baie ander soortgelyke primitiewe oortuigings - is ons, Christene, Jode, Afrikaniste nog lank nie verby nie. Trouens, ons tipiese manier van omgaan met die geskiedenis is juis om óns te laat goed lyk en om 'n paar individue van lank gelede te laat sleg lyk. Dan hoef ons mos nie te dink nie. Ons leer ook nie.

\section{SAMEVATTING}

In hierdie studie het ek eerstens probeer aantoon dat daar dinge is wat ons nie kan weet nie en dat ons dit eerder moet sê as om ander te verteken en sodoende ons eie integriteit prys te gee.

Tweedens, dat ons strewe moet wees om te interpreteer en te verstaan, en nie om anakronisties en etnosentries oor ander te dink nie. Hieruit volg dat ons nie sommer moet val vir die propaganda van ons bronne nie.

Derdens, dat historiese werk nie probeer swartsmeer of toesmeer nie. Daar is altyd helde en skurke, maar ons almal, nou, destyds en eendag, is maar net mense. So moet ons oor hulle dink, want so leer ons ook van onsself. Dit is juis hierdie selfreflekterende aspek wat ek as die belangrikste bydrae van historiese studie beskou. 'n Poging tot historiese verstaan is ' $n$ narratief oor mensself.

Met die oog op hierdie aspekte het ek Herodes die Grote ter illustrasie gebruik. Die korrektheid of finaliteit van my interpretasie van die gegewens is nie die primêre oogmerk nie: die illustrasie van die probleme en uitdagings van historiese verstaan wel. Die poging as sulks, om bilik en openhartig binne konteks te verstaan, is die sin.

Herodes konfronteer ons met heelwat vrae. Sou ek of jy anders gemaak het? Sou ons werklik gekies het om 'n 'commoner' te bly? Mens dink ook lank na oor mag, en die rol wat die sogenaamde 'groter perspektief' moet speel.

Die laaste woord gee ek aan Herodes (vir sover ons Josefus, $B J 1.390$, kan vertrou natuurlik):

Ek plaas myself in jou hande op gronde van my onkreukbaarheid, want ek glo dat jy nie sal wil weet wie my vriende was nie, maar watter soort van vriend ek was. 
* Ek bedank graag vir Johan Engelbrecht en Helen Botha vir hulle noukeurige lees van hierdie artikel. Soos altyd was Pieter Craffert en Vossie Vorster baie ondersteunend.

\section{Endnotas}

1 Hierdie is 'n baie tipiese en algemene indruk oor Herodes die Grote. (kyk o a Bruce 1962; Roetzel 1987:16). Gundry $(1982: 26,28)$ oordeel so: 'Herod ruled cleverly but cruelly .... harbored psychopathic suspicions'. Zeitlin (1969:37-38) sien Herodes as 'n homoseksuele tiran wat ook jong meisies verkrag en 'n onversadigbare bloedlus gehad het.

2 Alexander en Aristobulus, Herodes se seuns by Mariamme, wat mettertyd betrokke geraak het in 'n komplot teen hulle pa ( $A J$ 16.188-270). Smallwood (1976:101) oordeel dat hulle eerder die fokuspunt as die oorsprong van die komplot was.

3 Daar is heelwat samevattings oor Herodes se lewe en werk - kyk bv Brandon 1969:209-222; Schalit 1969b:70-73; Zeitlin 1969:3-57; Schalit 1971; Hoehner 1975; Freyne 1980:57-68; Levine 1992; Otzen 1990:33-45; Smallwood 1976:44-104. Vir meer uitvoerige studies kyk: Otto 1913; Jones 1938:35-155; Momigliano 1952; Perowne 1956; Grant 1971; Schürer, Vermes \& Millar 1973:267-335; Stern 1974 en die massiewe werk van Schalit 1969a. 'n Gebalanseerde oorsig word deur Grabbe (1992:320-366) aangebied.

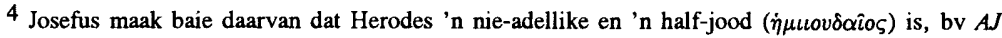
14.403. Talle skrywers aanvaar hierdie veroordeling as sou dit 'n duidelike en algemeen aanvaarde norm was vir mense se gedrag (kyk bv Bruce 1962:522; Schalit 1971:37), asof Joodse aristokratiese voorkeure oral oor as die toppunt van menslikheid gesien word. Sandmel (1962:590), teen alle getuienis in, beweer dat Herodes glad nie 'n Jood genoem kan word nie ('only by birth'); hy het hom hoegenaamd nie gesteur aan die mosaiese Wet nie.

5 Galilea deur Aristobulus 1, $103 \vee \mathrm{C}, A J$ 13.318, en Edumea deur Johannes Hirkanus ( $A J$ 13.255-258. Vergelyk ook Aleksander Janneus se optrede later, $A J$ 13.396-397) om-en-by $128 \mathrm{v}$ C (kyk Schürer, Vermes \& Millar 1973:207, 217-218).

6 Dit is uiters belangrik dat die 'rowerbendes' nie as 'n eenduidige fenomeen beskryf word nie, al gebruik Josefus dieselfde woord. Wat my ook opval in die debat hieroor, is die gemaklike manier waarop sosiale en ideologiese kategorieë gelyk gestel word. Diskussie: Loftus 1977; Smallwood $1981: 461-462$; Horsley 1979, 1988; Shaw 1984; Freyne 1988; Donaldson 1990. Sinvolle opmerkings by Rajak (1984:84-85): 'it is hard to estimate, from the writings left to us, the social component which this criminal behaviour undoubtedly contained'. 
${ }^{7}$ Die punt is nie dat demokrasie 'n moderne uitvindsel is nie. Herodotos (3.80-85) vertel van 'n gesprek wat beroemd geword het waarin demokrasie, oligargie en monargie teen mekaar opgeweeg word - natuurlik om aan te toon dat Darius se alleenheerskappy geregverdig is. En Josefus self kontrasteer die 'sekulêre' politieke opsies, monargie, oligargie en demokrasie (mag vir die massas volgens Josefus), met sý ideaal, teokrasie (Contra Apionem 2.164-167). Teokrasie is natuurlik ' $n$ aristokratiese oligargie met ' $n$ ander naam. Waaroor dit gaan, is dat begrippe soos totalitarianisme, despoot, demokrasie en selfs koning nie klakkeloos oor tyd heen gebruik word nie. Die suksesvolle ontwikkeling van demokrasie hang saam met 'n verwikkelde proses wat industrialisasie en verstedeliking omvat (Lenski, Lenski \& Nolan 1991:296-300). Verder is die ontwikkeling van die nasionale staatsbestel ook 'n voorwaarde (Dahl 1987:166). Die tradisionele stadstaat wat tot die einde van die $18 \mathrm{e}$ eeu samelewingsverhoudinge gedomineer het, was 'n heeltemal en al anderste konteks vir sogenaamde demokrasie (oftewel monargie). Die uitdaging is om die antieke monargiese politiek te verstaan en voor te stel vir wat dit was. 'n Deeglike bespreking vind mens in Finley 1985.

8 M $\alpha \rho \dot{\alpha} \mu \mu \eta \eta$ was die dogter van Aleksander, kleindogter van Hirkanus die hoëpriester en Aristobulus en dus deel van die Hasmonese familie. Sy was Herodes se tweede vrou (BJ 1.241). Herodes was 5 jaar lank verloof aan haar, alvorens die troue in 37 v C plaasvind, terwyl hy Jerusalem beleër het. Josefus vertel dat Mariamme 'n beeldskone vrou was wat 'n geweldige seksuele houvas op Herodes gehad het: 'Fully conscious of her power over her husband, she exploited it mercilessly. There were violent quarrels, but Herod was too deeply in love to keep up his anger long and a reconciliation always followed' (Jones 1938:55, bykans verbatim by Josefus afgeskryf). Sy het uiteindelik gepoog om Herodes te vergiftig, 'n poging wat nie te goed vir haar eie lot uitgewerk het nie (alhoewel Josefus die komplot aan Herodes se suster Salome toedig, $A J$ 15.224-228). Josefus teken haar as 'n edelvrou wat besonder trots is op haar aristokratiese

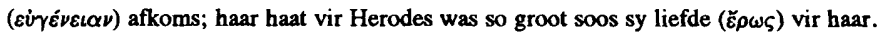

Dit is uiters belangrik om Herodes se baie huwelike binne die konteks van eerste-eeuse Mediterreense verwantskapswaardes (kinship values; vgl Hanson 1989a, 1989b) te lees. Die intriges in Herodes se gesin was in die eerste plek uitinge van destydse opvattinge van status en gesag. Vir Herodes se harem, kyk $B J$ 1.562-563, $A J$ 17.19-22, maar Josefus sluit nie Marriamme 1 by die 9 vroue in nie.

9 Kleinseun van Herodes en Mariamme 1, seun van Aristobulus en Berenike, koning van Judea 37 (of 40)-44. Die skrywer van Handelinge (12.1) noem hom verkeerdelik Herodes (Agrippa). Sy naam was waarskynlik Markus Julius Agrippa (Grabbe 1992:430) en hy was 'n regte verkwister, voortdurend in die skuld. (kyk $B J$ 2.178-219; $A J$ 18.126-309, 19.212-359). 
10 Klein-kleinseun van Herodes, koning van Galilea, Gaulanitis, Tragonites en Galkis/Abila 50(?)-95. Hy is die eerste van die Herodiaanse familie wat sy volle Romeinse naam amptelik gebruik het (Kaisar het aan Herodes burgerskap gegee): op muntstukke is hy Marcus Julius Agrippa, en op 'n inskripsie: Die groot koning, vriend van die keiser, die vrome, vriend van Rome. Agrippa 2 was ook een van Josefus se bronne (Josefus verwys na korrespondensie tussen hulle ensomeer, Vita 362-367), of minstens het hy Josefus se werke aanbeveel.

11 Getrou aan die aard van die genre waarin Josefus skrywe, is die beskrywing van Herodes se siekbed en sterfte 'n Grieks-Romeinse topos (Ladouceur 1981). In BJ 1.656 ly Herodes omdat

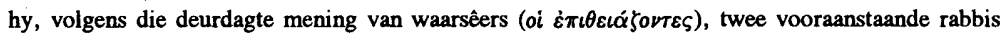

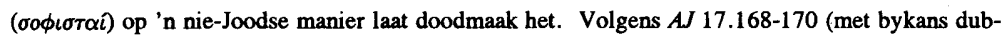
bel soveel detail in verband met Herodes se kwale) word die rede baie meer algemeen: die koning se wetteloosheid en goddeloosheid ( $\left.\delta v \sigma \sigma \varepsilon \beta_{\varepsilon} \alpha\right)$. Vir Josefus lei die optrede teen die rabbis na 'the pestilence of pestilences, the Athenian plague' (Ladouceur 1981:33; Josefus sinspeel op Tukidides 2.49.2-6).

12 Dit is nie onbelangrik om te vermeld dat in hierdie geval (Hirkanus, die vroeëre-hoëpriester) die sogenaamde nuwe getuienis bestaan uit karaktereienskappe (Hirkanus was saggeaard en het nie in sy jeug enige teken gegee van durf of roekeloosheid nie - vgl $A J$ 15.177) en dat hy 'n tagtigjarige ou man was wat nie 'n bedreiging vir Herodes kon gewees het nie.

13 Dit lyk my redelik seker nie soseer omdat hy sulke aansprake met sy geslagsregister maak nie (Vita 1-6) - daar is te veel probleme in opgesluit om dié as betroubaar te aanvaar - maar veral omdat sy voorkeur so sterk deurslaan in sy verhale.

${ }^{14}$ Goldstein (1973) wys egter daarop dat hierdie konklusie nie so duidelik is nie, dit skep ook weer nuwe probleme. Óók TMos 6-7 kan gelees word teen die agtergrond van Antiogus 4 en Apollonius se aanvalle, alhoewel hy toegee dat daar waarskynlik 'post-Herodian alterations' voorgekom het.

15 Die impak van Matteus se verhaal blyk o a in die honderde (indien nie duisende nie) kunswerke wat die moorde uitbeeld (voorbeelde in Grant 1971 passim).

16 Vir hierdie en die volgende paragrawe veronderstel ek dat die 'koning van die Judeër' minstens ook verantwoordelik was vir dit waarvoor 'n Romeinse goewerneur van 'n provinsie was, oftewel dan baie soortgelyke verpligtinge; kyk Brunt 1975 vir 'n deeglike uiteensetting van die goewerneurskap van Egipte. 


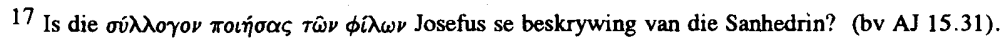
Schalit (1969a:251-253) bespreek die moontlikheid dat daar 'n 'Gerichtshöfe des Herodes' kon bestaan het om sake aan te hoor op gronde van die Romeinse reg. Natuurlik sou hierdie net 'n klomp lakeie van die koning gewees het, aldus Schalit. Smallwood bespreek die moontlikheid dat daar twee Sanhedrins was (1976:32 n 36), maar vergelyk Grabbe (1992:390-391) se sinvolle beoordeling.

18 Schalit (1969a:247vv) wys daarop dat ons hier waarskynlik sien hoe Herodes die fyn lyn tussen 'n dubbele verantwoordelikheid handhaaf, te wete teenoor die Romeinse Ryk asook teenoor sy land self. Oktavianus het naamlik, in sy strewe om die Romeinse ryk se etiese standaarde op te hef, wette gemaak dat 'openlike diewe' (diewe wat in die nag steel of gewapend in daglig) doodgemaak moes word. Joodse gebruik was 'n restitusie van die waarde gesteel, en as dit nie moontlik is nie, verkoping as slaaf slegs aan Jode en slegs vir 'n tydperk van 6 jaar (AJ 16.3). Schalit self meen dat Herodes eintlik hier optree teen diegene wat sy koningskap nie steun nie (vryheidsvegters wat terreur beoefen teenoor die Herodiaanse ondersteuners) wat hy nie andersins kon bykom nie. 'n Mens wonder wat het diegene gesê wat aangerand en besteel is deur hierdie rowerbendes, en hoekom Herodes sulke ingewikkelde stappe sou neem om van sy opponente ontslae te raak.

19 Talle skrywers beskryf die 'polisiestaat' van Herodes (Jones 1938:92; Grant 1971:122; Fenn 1992:7, en andere). Maar die betrokke gedeelte in Josefus sê nie heeltemal dit nie: dit is nogal duidelik dat die 'spioenering' gerig is op 'n spesifieke groep, dat dit vir 'n bepaalde tyd was, en dat dit in en rondom 'die stad' plaasgevind het $-A J 15.366$.

20 Herodes moes ongelooflik ryk gewees het. Hy was 'n baie suksesvolle sakeman. 'n Paar voorbeelde van sy bedrywighede: saadtransaksies met Sirië en in Klein-Asië met 'n winskoers van $50 \%$, belasting op handelsroetes deur Idumea (Negeb), hy het verskeie banke gestig, en in 12 v C die kopermyne van Siprus by Oktavianus gekoop vir 300 talente (waarmee hy die oosMediterreense mark verower het). Sy konfiskasie van baie Hasmonese eiendomme (nog 'n steen des aanstoots vir Josefus) het natuurlik goed bygedra tot opgestopte geldkoffers.

21 'n Tragiese maar algemene verskynsel:

what we know about other eastern Mediterranean courts during these centuries suggests that the sordid horrors at the court of Jerusalem were very far from unique. They are merely better known than the others, owing to the accident that Josephus' accounts have survived .... a rich mine of authentic squalor [about other Hellenistic monarchs] has been lost. Nor is one entitled to adopt the superior occidental view that there was 
something specially eastern about all these murders within the family; a glance at the pages of Tacitus and Suetonius will recall that imperial Rome was seething with murderous domestic strife.

(Grant 1971:232)

En Perowne (1956:18-19) se opmerkings: 'In those days to be a king's brother was a dangerous calling which nearly always brought death or insurrection. Indeed, Plutarch tells us that among the Seleucids (as afterwards with the Ottomans) it was regarded as a "mathematical axiom" that on attaining the throne, a king should murder all his brothers'.

22 Josefus beklemtoon Herodes se persoonlike betrokkenheid by die bouprogram ( $A J$ 15.420). Dit is moontlik dat Herodes hoofsaaklik vir 'utilitarian and practical purposes' gebou het, en ongetwyfeld was hy persoonlik betrokke gewees by die ontwerp en bou van sy talle konstruksies (cf McRay 1991:95), maar die godsdienstige toon van die geboue moet nie onderskat word nie. In ' $\mathrm{n}$ sin is dit die enigste 'tekste' van Herodes self waaroor ons beskik.

23 Ons weet vandag dat die 'klassieke' beeld van antieke Judaïsme 'n totaal oordrewe rol aan die Fariseërs toeken. Dat Farisese groepe nie van Herodes gehou het nie, is duidelik (Alon 1977:3840), maar 'n persoon kan tog nie aan die hand van 'n bevooroordeelde (minderheids-)perspektief summier veroordeel word nie (soos Alon in der waarheid doen) (kyk vir soortgelyke probleme in verband met Domitianus, Botha 1989:52-55).

\section{Literatuurverwysings}

Alon, G 1977. The attitude of the Pharisees to Roman rule and the House of Herod, in Alon, G, Jews, Judaism and the classical world: Studies in Jewish history in the times of the second temple and Talmud, 18-47. Jerusalem: Magnes Press.

Attridge, H W 1984. Josephus and his works, in Stone, M E (ed), Jewish writings of the second temple period: Apocrypha, Pseudepigrapha, Qumran Sectarian Writings, Philo, Josephus, 185-232. Assen: Van Gorcum.

Bauman, Z 1992. Hermeneutics and social science: Approaches to understanding. Hampshire: Gregg Revivals.

Botha, P J J 1989. The historical Domitian - illustrating some problems of historiography. Neotestamentica 23, 45-59.

1990. Mute manuscripts: Analysing a neglected aspect of ancient communication. Theologia Evangelica 23 (3), 35-47.

1992a. Greco-Roman literacy as setting for New Testament writings. Neotestamentica 26, 195-215. 
Botha, P J J 1992b. Letter writing and oral communication in antiquity: Suggested implications for the interpretation of Paul's letter to the Galatians. Scriptura 42, 17 34.

- 1993. The social dynamics of the early transmission of the Jesus tradition. Neotestamentica 27, 205-231.

Bracher, K D 1987. Totalitarianism. s v The Blackwell encyclopaedia of political institutions, 614-616.

Brandon, S G F 1969. Religion in ancient history: Studies in ideas, men and events. New York: Charles Scribner.

Braund, D 1984. Rome and the friendly king: The character of the client kingship. London: Croom Helm.

Broshi, M 1987. The role of the temple in the Herodian economy. JJS 38, 31-37.

Bruce, F F 1962. Herod. s v New Bible Dictionary, 521-523.

Brunt, P A 1975. The administrators of Roman Egypt. Journal of Roman Studies 65, 124-47.

Charlot, M 1987. Monarchy. s v The Blackwell encyclopaedia of political institutions, 374-376.

Dahl, R A 1987. Democracy. s v The Blackwell encyclopaedia of political institutions, 166-169.

Donaldson, T L 1990. Rural bandits, city mobs and the Zealots. Journal for the Study of Judaism 21, 19-40.

Downing, F G 1982. Common ground with paganism in Luke and in Josephus. NTS 28:546-59.

DuBois, P 1991. Torture and truth. New York: Routledge.

Fenn, R K 1992. The death of Herod: An essay in the sociology of religion. Cambridge: Cambridge University Press.

Finley, M I 1985. Democracy ancient and modern. 2nd ed. London: Hogarth.

Fischer, J L 1963. The sociopsychological analysis of folktales. Current Anthropology $4,235-295$.

Fitzmyer, J A 1981. The gospel according to Luke (I-IX): Introduction, translation, and notes. Garden City: Doubleday.

Freyne, S 1980. Galilee from Alexander the Great to Hadrian 323 B C E to 135 C E: A study of second temple Judaism. Wilmington: Michael Glazier.

- 1988. Bandits in Galilee: A contribution to the study of social conditions in first-century Palestine, in Neusner, J, Frerichs, E S, Borgen, P \& Horsley, R (eds), The social world of formative Christianity and Judaism, 50-68. Philadelphia: Fortress Press. 
Gihon, M 1967. Idumea and the Herodian limes. Israel Exploration Journal 17, 2742.

Goldstein, J A 1973. The Testament of Moses: Its content, its origin, and its attestation in Josephus, in Nickelsburg, G W E (ed), Studies on the Testament of Moses, 44-52. Cambridge (Mass.): Society of Biblical Literature.

Grabbe, L L 1992. Judaism from Cyrus to Hadrian, Vol 2: The Roman period. Minneapolis: Fortress.

Grant, M 1971. Herod the Great. London: Weidenfeld \& Nicolson.

Groenewald, E P 1968. Handboek Bybelse geskiedenis; 2: Die Nuwe Testament. Pretoria: Interkerklike Uitgewerstrust.

Gundry, R H 1982. Matthew: A commentary on his literary and theological art. Grand Rapids: Eerdmans.

Hanson, K C 1989a. The Herodians and Mediterranean kinship, part 1: Genealogy and descent. Biblical Theology Bulletin 19, 75-84.

1989b. The Herodians and Mediterranean kinship, part 2: Marriage and divorce. Biblical Theology Bulletin 19, 142-151.

Hoehner, H W 1975. Herod. Zondervan Pictorial Encyclopedia of the Bible 3, 12646.

Horsley, R A 1979. Josephus and the bandits. Journal for the Study of Judaism 10, 37-63.

1988. Bandits, messiahs, and longshoremen: Popular unrest in Galilee around the time of Jesus, in Lull, D (ed), SBL 1988 Seminar Papers, 183-99. Atlanta: Scholars.

Jagersma, H 1985. A history of Israel from Alexander the Great to Bar Kochba. London: SCM.

Jones, A H M 1938. The Herods of Judaea. Oxford: Clarendon.

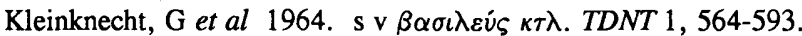

Ladouceur, D J 1981. The death of Herod the Great. Classical Philology 76, 25-34.

Lenski, G, Lenski, J \& Nolan, P 1991. Human societies: An introduction to macrosociology. 6th ed. New York: McGraw-Hill.

Le Roux, J 1977. Die Romeinse tydperk, in Van Zyl et al 1977:256-290.

Levine, L I 1992. Herod the Great. Anchor Bible Dictionary 3, 161-169.

Loftus, F 1977. The anti-Roman revolts of the Jews and the Galileans. Jewish Quarterly Review 68:78-98.

Luz, U 1985. Das Evangelium nach Matthäus, 1 Bd: Mt 1-7. Zürich: Benziger Verlag.

McRay, J 1991. Archaeology and the New Testament. Grand Rapids: Baker.

Meshorer, Y 1967. Jewish coins of the second temple period. Tel-Aviv: Am Hassefer. 
Millar, F 1967. Emperors at work. Journal of Roman Studies 57, 9-19.

Momigliano, A 1952. Herod of Judaea. Cambridge Ancient History 10, 316-339.

Nickelsburg, G W E 1987. Jewish literature between the Bible and the Mishnah. 2nd ed. Philadelphia: Fortress Press.

Otto, W 1913. Herodes, Herrscher von Judaea. Paulys Real-Encyclopädie Suppl 2, 1158.

Otzen, B 1990. Judaism in antiquity: Political developments and religious currents from Alexander to Hadrian. Sheffield: Sheffield Academic Press.

Perowne, S 1956. The life and times of Herod the Great. London: Hodder \& Stoughton.

Priest, J 1983. Testament of Moses: A new translation and introduction, in Charlesworth, J H (ed), The Old Testament pseudepigrapha, Vol 1: Apocalyptic literature and testaments, 919-934. London: Darton.

Rajak, T 1984. Josephus: The historian and his society. Philadelphia: Fortress.

Rawson, E 1975. Caesar's heritage: Hellenistic kings and their Roman equals. Journal of Roman Studies 64, 148-159.

Richardson, P 1986. Law and piety in Herod's architecture. Studies in Religion 15, $347-60$.

Roetzel, C J 1987. The world that shaped the New Testament. London: SCM.

Sandmel, S 1962. Herod (family). s v IDB 2, 585-594.

Schalit, A 1969a. König Herodes: Der Mann und sein Werk. Berlin: De Gruyter.

1969b. Palestine under the Seleucids and Romans, in Toynbee, A (ed), The crucible of Christianity: Judaism, Hellenism and the historical background to the Christian faith, 65-76. London: Thames \& Hudson.

- 1971. Herod and his successors, in Schultz, H J (ed), Jesus in his time, 36-46. Philadelphia: Fortress Press.

Schürer, E, Vermes, G \& Millar, F 1973. The history of the Jewish people in the age of Jesus Christ (175 B C-A D 135), Vol 1. Rev ed. Edinburgh: Clark.

Shaw, B D 1984. Bandits in the Roman Empire. Past and Present 105, 3-52.

Smallwood, E M 1976. The Jews under Roman rule: From Pompey to Diocletian. Leiden: Brill.

- 1981. Introduction, notes and appendices, in Williamson, G A (trans), Josephus: The Jewish war. Rev ed, 9-24, 409-471. Harmondsworth: Penguin.

Stern, M 1974. The reign of Herod and the Herodian dynasty, in Safrai, S \& Stern, M (eds), The Jewish people in the first century: Historical geography, political history, social, cultural and religious life and institutions, Vol 1, 216-307. Philadelphia: Fortress Press. 
Van Zyl, A H et al 1977. Israel en sy bure. Durban: Butterworths.

Zeitlin, S 1969. The rise and fall of the Judean state: A political, social and religious history of the second commonwealth, Vol 2: 37 B C E - 66 C E. Philadelphia: Jewish Publication Society of America. 